\title{
IMPACT OF INFLATION RATE AND EXCHANGE RATE ON GDP: EVIDENCE FROM PAKISTAN
}

\author{
Muhammad Mohsin \\ PhD Scholar \\ Liaoning Technical University, China \\ mohsinlatifntu@gmail.com \\ Muhammad kashif Majeed \\ Liaoning Technical University, China \\ SobiaNaseem \\ Liaoning Technical University, China
}

dol http://dx.doi.org/10.26739/2573-5616-2018-3-2-3

\begin{abstract}
This is used to find the empirical relationship macroeconomic variables and Gross domestic product (GDP). Annually data are used 1980 to 2017 to found this relationship.In previous study different research used different technique but most of the researcher used econometric multiply regression are used to found the relationship. In this study also used the multiply regression to found the impact of inflation rate (IN) and Exchange rate (EX) on GDP. The result shows that the inflation exchange rate is positively significant at $1 \%$ level with GDP. Both variables show the impact on GDP. This study is helpful for Pakistani economy and policy maker these policy maker should be controlled the inflation rate because inflation shows the significant relation with GDP.
\end{abstract}

Key words: Gross domestic product, Inflation rate, Exchange rate, regression technique.

\section{Introduction}

In last few decades economic growth in Pakistan is not good. Many factors are responsible for unsatisfactory of GDP: raising the growth rate of imports, lack of exports, highly inflation rate, unsatisfactory banking system, raising interest rate, growth rate of population increased and political instability. The economic growth is helpful to increase the income of humankind and help the country to decrease the unemployment rate. When inflation is increase, investment reduced which had bad effect on economic growth of any country.

The basic challenge for economics is to understand the nature and causes of economic progress. Ricardo (1817) analyzed that total goods 
and services produced in a country are the best scale to know economic progress. The economy is like a machine of any country: which transforms inputs to outputs. After the World War II, most of the countries adopted aggressive economic policies to improve the growth rate of real gross domestic product (Crafts, 2000).

FDI is principal source for economic development of any country. The high inflation rate and low investment is major problem for economy of Pakistan. The exchange rate volatility leads to lower the exports. Rising in exchange rate volatility has significant and risky effect on export. The volatility in exchange rate has also effect on the policy maker. The volatility in exchange rate is leads to decline trade of any country.

Economic growth enhances the income of society and decrease the unemployment level of acountry.Last few decades the relationship between the economic growth and macroeconomic variables become severe issue among researcher. Foreign direct investment is a major source of increasing economic growth.The GDP rate and interest rate have inverse relationship. The interest rate volatility is strongly relationship with inflation. If the inflation rate is high then the interest rate obviously high. When the conduction is favorable the low interest rate due to low inflation rate: that's better for economic growth for a country. If the interest rate is higher than the economic growth will be decreased.The relationship of interest rate and growth rate is significant. If the literacy rate increases leads to increase the productivity and decrease the poverty, so due to this the economic growth will become increase. Education is development process by two ways: in one side it leads to reduce the poverty and on the other side it boosts up the economic growth.If the volatility in exchange rate then the uncertainty environment for investment in that country. Almost last 35 years the exchange rate in Pakistan was maintain through regime system, but now it is determined through weighted average method of Pakistani currency with the other trading partner currency. Lucas (1988), Romer (1990) and Grossman and Helpman (1991) establishedthe endogenous growth theory. The policy creator and economists are interested in sustainable level of economic growth and are much worried in downward movement of economic growth.

Barro (1991), Baker (1998) and Caballero (2007) investigate that internal and external factor are responsible for unbalanced economic progress. Three source of instable gross domestic product in developing countries like as Pakistan. First one is big unexpected shocks which come from financial markets and terms of trade. Second one is that less developed nation domestic shocks due to basic instability and self-predication. Third one is the most important factor that underdeveloped nations have weak capacity to absorb the shocks. 


\section{Objective of study}

F To found the relationship of Inflation rate, Exchange rate On Gross domestic Product.

\section{Literature Review}

Jalni at el. (2010) found that there is significant impact of inflation rate, exchange rate and interest rate on GDP. But the sing of coefficient of inflation and interest rate showed negative relation with GDP while exchange rate is positively significant with GDP. In this study used the regression technique to found the result. Sajid at el., (2014) reveled that inflation rate, interest rate, exchange rate and FDI showed the significant impact on GDP growth. This result is helpful for SBP should adopt monetary policy to reduce the impact of inflation rate. In this study the researcher used the regression technique to found out the result and also used the Granger causality test technique is used found that all independent variables showed unconditional relation with GDP.

Rehman (2015) conducted a study to found the answer of question is macroeconomic variables has a relation with GDP. In this study used ARDL technique to found the long and short run relation with GDP. The result of this study showed that existence of con-integration between macroeconomic instability and macroeconomic variables. The result also showed that macroeconomic variable has deep rooted impact with exchange rate. Kashif (2016) used multiply regression technique to found the macroeconomic variables impact on GDP. The result showed that the inflation rate, interest rate had a negatively significant relationship with GDP while exchange rate had positive relationship with exchange rate. This study is helpful for Government to take strict policies due to inflation because in this study inflation showed a significantly relation with GDP. Ghani et al. (2016) found that there is a long run positive association among the variables, the exchange rate and money supply positivity influenced the economic growth. Inflation rate effected positively but insignificant this research suggested that a stable exchange rate policy is enhanced to control the economic growth. Raseed (2013) used the VARBased technique and Johansen Co-integration approach to found the macroeconomic variables and GDP long and short run relationship. The Result showed that the coefficient of agricultural, services, trade openness and exchange rate positively and significantly impact on GDP. Aftab (2015) showed that the used multiple linear regression models to found relationship between inflation rate, interest rate and GDP the result showed that inflation rate is negative significant impact on GDP and the exchange rate had positively significant on the economic growth but in Pakistani economy these are all variables is less important but the politically condition of a country is important. Shah and Ayub (2015) proved that 
money supply, inflation rate and interest rate are effected the GDP the coefficient of these entire variable affected the exchange rate positively and significant.

H0: There is no significant relationship between Inflation rate, Exchange rate and Gross Domestic product.

H1: There is significant relationship between Inflation rate, Exchange rate and Gross Domestic product.

\section{Data Description}

For this research the time series secondary data from 1980 to 2017 was used. The date is obtained from State Bank of Pakistan, World Bank Development Indicator, Business recorder and also some findings and the information about data was gathered previous report, research paper and official websites.

\section{Methodology}

To found the impact of macroeconomic variables on exchange rate the multiple econometric regressions is used.This model is also used by Zamer (2017). The model is constructed as follows.

$$
\text { GDP }=\mathrm{f}(\mathrm{IN}, \mathrm{EX})
$$

The regression equation model and take natural logarithm is as follows.

$$
\mathrm{GDPt}=\beta 0+\beta \mathrm{INt}+\beta \mathrm{EXt}
$$

Where,

GDP $=$ Gross domestic Product

$\mathrm{IN}=$ Inflation

$\mathrm{EX}=$ Exchange rate

$\mu \mathrm{i}=$ Error Term.

\section{Empirical Result}

\section{Table\# 1}

\begin{tabular}{|l|r|r|r|}
\hline \multicolumn{5}{|c|}{ Descriptive statistics } \\
\hline & GDP & IN & EX \\
\hline Mean & 2.301629 & 8.123425 & 125.6323 \\
\hline Median & 2.2354 & 7.766884 & 112.9396 \\
\hline Maximum & 6.685581 & 20.28612 & 226.4974 \\
\hline Minimum & -1.449514 & 2.539516 & 93.48988 \\
\hline Std. Dev. & 1.866792 & 3.936746 & 37.67545 \\
\hline
\end{tabular}


In the above table shows that the value of GDP mean is 2.30 , IN is 8.12 and the mean value of exchange rate $(\mathrm{EX})$ is 125.63 . Median is 2.23 of GDP, 7.76 of IN and EX value median value is 112.93. In above table also shows the values of minimum, maximum and stander deviation. The number of values is 38 included in this study.

Table\# 2

\begin{tabular}{|l|r|r|r|}
\hline \multicolumn{7}{|c|}{ Correlation Matrix } \\
\hline & GDP & IN & Ex \\
\hline GDP & 1 & -0.2172 & 0.38974 \\
\hline CPI & -0.2172 & 1 & -0.08895 \\
\hline RE & 0.38974 & -0.08895 & 1 \\
\hline
\end{tabular}

The table 2 shows that correlation among variables the GDP and IN is negative correlated, the Exchange rate (EX) is positive correlated but the exchange rate and inflation rate is negative correlated.

Table \# 3

\begin{tabular}{|c|c|c|c|c|}
\hline \multicolumn{5}{|c|}{ Regression Result } \\
\hline Dependent Variable: GDP & & & & \\
\hline Method: Least Squares & & & & \\
\hline Sample: 138 & & & & \\
\hline Variable & Coefficient & Std. Error & $\begin{array}{l}\mathrm{t}- \\
\text { Statistic }\end{array}$ & Prob. \\
\hline $\mathrm{C}$ & 0.686109 & 1.198379 & 0.572531 & 0.5706 \\
\hline $\mathrm{IN}$ & 0.087245 & 0.072627 & 1.201274 & 0.0477 \\
\hline EX & 0.0185 & 0.007589 & 2.437825 & 0.02 \\
\hline R-squared & 0.18548 & Mean dependent var & & 2.301629 \\
\hline Adjusted R-squared & 0.138936 & S.D. dependent var & & 1.866792 \\
\hline S.E. of regression & 1.732262 & Akaike info criterion & & 4.01239 \\
\hline Sum squared resid & 105.0256 & Schwarz criterion & & 4.141673 \\
\hline Log likelihood & -73.23541 & Hannan-Quinn criter. & & 4.058388 \\
\hline F-statistic & 3.985054 & Durbin-Watson stat & & 1.196179 \\
\hline Prob(F-statistic) & 0.027592 & & & \\
\hline
\end{tabular}

In above table shows the result of regression analysis. The result shows that inflation rate (IN) Exchange Rate (EX) is positively significant with GDP at $1 \%$ level of significance. The value of F-statistics 3.985054 which is significant at $1 \%$ level of significance which means the model is good fit. 


\section{Conclusion}

The Gross domestic Product (GDP) is of the most important tool that is used to measure of economy output production. So the GDP is defined the value of goods and services produced within a country in a specific period. In this study found the relationship between GDP, inflation and Exchange rate. Exchange rate found positively significantly with GDP. But the inflation rate is found no relation with GDP. GDP is best signal indicator of economic growth. Many other variables impact on Gross domestic product (GDP).

\section{References}

1. Agalega, E., \& Antwi, S. (2013). The Impact of Macroeconomic Variables on Gross Domestic Product: Empirical Evidence from Ghana. International Business Research.

2. Ahmad, D., Afzal, M., \& Ghani, U. (December, 2016). Impact of Monetary Policy on Economic Growth Empirical Evidence of PAkistan. International Journal of Applied Economic Studies.

3. Ali, A., \& Rehman, H. U. (2015). Macro Economic Instability and Its Impact on Gross Domestic Product An Empirical Analysis of Pakistan . PAkistan Economic and Social Review , 285-316.

4. Ayub, S., \& Shah, F. M. (December, 2015). Impact of Monetary Policy on Gross Domestic Product (GDP). Asian Journal of Business and Management .

5. Chughtai, M. W., Malik, M. W., \& Aftab, R. (2015). Impact of Major Economic Variables on Economic Growth of Pakistan . ACTA UNIVERSITATIS DANUBIUS.

6. Farooq, M. U., Sabir, D. M., Tahir, S. H., \& Rasheed, M. K. (2013). Key Factor Affecting GDP in Pakistan over the Period 1975-2011. Journal of Economic and Sustainable Development.

7. G.A, A., P.I.P, O., \& Ph.D, O. D. (Jan-Feb 2018). Analysis of inflation and Its Effect on Economic Growth in Nigeria . Journal of Economics and Finance , 28-36.

8. Hussain, A., Sabir, H. M., \& Kashif, M. M. (June,2016). Impact of Macroeconomic Variables on GDP:Evidence from Pakistan. European Journal of Business and Innovation Research , 38-52.

9. Jilani, S., Cheema, F.-E.-A., \& Asim, M. (2010). Exploring Impact of Macro Economic Variables on GDP in Pakistan. Journal of Management and Social Sciences, 65-73.

10. Karman, M., Arshad, M. U., Imdad, S., \& Kibira, U. (September(2014)). Exploring the Impact of Macro Economic Variables on GDP Growth of Pakistan. Research Journal of Management Sciences , 1-6.

11. Ume, A., \& Hameed, I. (December, 2011). Impact of Monetary Policy on Gross Domestic Product (GDP) . Interdisciplinary Journal of Contemporary Research in Business. 